\title{
ASPERGILLUS INFECTION IN LAYER HENS
}

\author{
Elwan, F. I.; Manal, A. M. El-Maslamy and Alam, H. H.

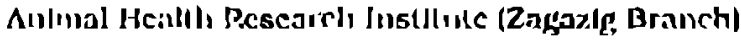

\begin{abstract}
Two hundreds of layjer chickens were scmpled from 100.000 layer hens of different ages that showing clinical signs and gross lesions from different jams in Sharka Governorate from Jamuary to April-2008. Aspergillus spp. were isolated and identified morphologically on cultural basis. Morbidily rate was reached $40 \%$ and morlally rate inore 7\%. Clinical signs were mainly resplratory characterlzed by gasping, dyspnea and accelerated breath. The most common gross lestons were caseated nodules distributed in lung, air sacs, intestine, heart and liver. Microscopic pichure revealed granulomatous lesions with or wilhoul hyphine. Those lesions represented by caseated nodules, numerous inflammatory cells mainly helerophils, lymphocutes, maciophages and giant cells. The nodules were encapsulated with thin conneclive tissue capsule. The fungal hyphae appared as branching thread-like either at the periphary or inside the organs parenchyma. Control of aspergillosis in our present study illustrated that there was no curative treatment for aspergillosis.
\end{abstract}

\section{INTRODUCTION}

Mycloic disease in chicken liad been reported early by Rowell (1949), tt causc high ceonomic losscs particularly ivhen assoeiatcd wilh ollier stress conditions (Ononlwu and Momoh 1983).

Many authors Isolated Asperglllus spp. as an etiological agent of inycolic infection eausing death، (Pandita et al., 1991: Droval et al., 1994: Als 1996 and Sami \& Sabry 2004).

Fungal infeetion consider to be a stress factor allcclung hatchability, growlh and development of blrds (Cutsen and rram 1987 and El-Badry and Sokkar 1988).

Avian asperglllosis causcd by $\Lambda$ sperglllus fumigatus, Asperglllus havus or Aspergillus nidulans and characlerlzed by grantiomatous ieston in respiratory tract (Croksh 1982: Ibrahlm et al., 1983; Mieoyie et al., 1986; El-Bardy and Gokkar, 1988 and Pal et al., 1980).

Hyglente conditions of chicken floeks such as warm, humidty, floor brooders and houses play an important role in the pathogenesls of this fungal infection (Beckman et al., 1994)

'The alm of the present work was to study the incidenee of Asperglliosls (ellnical signs, isolation of causattve agents, the gross and inicroscoplc lesions) among slck and or healthy layer flocks. 


\section{MATERIAL AND METHODS}

A total number of 200 chlckens from 100.000 layer hens of different ages that showing clinical signs and gross leslons tvere collected from different, farms at Shatr'a Jovernorate during the perlod fron January to $\Lambda$ pril-2008. Investigated chlckens were elther clinically sick or recently dead. Layers were fed on well balaneed ratlon that contain recommcnded requlrements and vaccinated with the reeonmended vacelnes beside having prophylactic antlbacterial and antlcoeldial diugs.

Clinieal signs and gross plctures were recorded. Spccimens from lesions in different organs were collccted for Isolation and idcutification Asperiglus according to Al-Doory (1980).

Swabs from alr saes, lung. heart. liver, spleen and kidneys fron diseased chickens were eultured on Sabouraud's agar (AlDoory, 1980) contalnlug 100ug/ml gentamycin sulfate and incubated at $24^{\circ} \mathrm{C}$ to isolate Aspergillus spp.

Pathogenesily of Aspergillus fumigatus: 90 layer chickens of 4 weelss old were distributed into 3 groups (A. B and C). Group (A) was kept as a control (non infected and non treated). Groups (B \& C) were Inoculated $\mathrm{I} / \mathrm{M}$ with $\mathrm{I} \mathrm{lnl}$ containing $10.5 \times 10^{4} \mathrm{C}$.F.U. of aspergillus fumigatus (Beckman et al., 1894).

Group (C) was treated $24 \mathrm{~h}$. post Infection with griseolvin $20 \mathrm{mg} / \mathrm{kg}$ body welght for 5 successive days in drinking water. All birds ivere kept under observation for 14 days

\section{Histopathological examination:}

Fresh speelmens from lung, alr sac. liver and heart wrere flxed in 10\% neutial buffered formalln. Рaramin seetions of 5 mlcrons thick were prepared and stained with hematoxylin and eosin according to Lulle, 1984 and Bancroft et al.. 1900.

Pathngenlcty of Asperglllus fumigatus to 4 weeks old layer chicks:

Inoculcated birds of group $B$ and $C$ showed high inorbldity compared wilh birds in control group (A). birds in group $C$ (treated) showed low mortallty. We can re-Isolating Asperglllus fumigatus from both groups $\mathrm{B}$ and C. (Table 2).

\section{DISCUSSION}

This work declared that the pereentage of mortality was 7\% among flocks of layer naturally infeeted with Aspergillosis. This was in accordance tvith Beckman et al., (1904) who mentioned that the suseeptibility of the young chicks to Asperglllosis increased due to Imnaturity of phagocytcs or due to environmental factors.

Aspergllus Infection in the present study was characterized by high morbidity and low mortality.

The clinical signs in the present study ivere mainly resplratory manifestallons characterlzed by gasping and dyspnea. These slgns were also reported by Edris et al., (1995): Calneci et al., (1991) and Sami and Sabry (2004). These signs Indicated that aspergillosls was consldered an alr born disease and the severity of outbreak was related to the spore coneentration in the air.

Cnineck et al., (1991) mentioned that the outbreak oceurred when the organism was present in suflcient quantities to establish the clisease or when birds resistance was Impaired by Immuno suppressive compounds. 
The gross leslons of aspergillosis in the present investigation were detected in the lung. alr sac, heart, liver and Intestine. The widely disseminated infection to these organs may be due to hematogenous or lymphatic dissemination of the organlsm from resplratory tract to these organs, these observations agreed wth Beckman et al., (1994). The gross lesions were small whit-yellowlsh and fragile. Caseatcd nodules of $1-2 \mathrm{~mm}$ thlckness distributed in the infected organs. Gab-Allah, (1994); Richard et al., (1994) and All (1996) described white nodular lesions of varlable thickness in lungs, alr sacs, liver and intestine.

The microscopic plcture was characterized by granulomata with or without hyphae, the granuloma represented by caseated nodules with numerous inflammatory celis malnly heterophils, lymphocytes. maerophages and glant cells. Thin fibrosis capsule was encapsulated the nodules.

These lesions showed partlal agreement with Mahmoud (1988) and Edris et al., (1995) who found passive congestion and wde infiltration of inflammatory eells in pulmonary tissue of plgeon and Guined fowl, respectively. They also detected granulomatous lesions of different sizes contalning fungl hyphae in air sacs, lungs, liver and intestine. Hemosiderosis seen In liver was due to destruetion of erytherocyte by fungl and their toxins, this result agreed with Edris et al., (1995) who detected hepatic hemosiderosls followng natural Aspergillosis in Guinea fowl. Heavy lymphoeytic Infiltration was observed In the eardlac muscles and that In agreement with Mitrolu et. al. (1982) who observed histocytie and lymphocytic infiltration in the cardlac muscles whlle Mahmoud (1988) noticed nelther gross nor histopathological changes In the heart.

Pathogenisty of Aspergillus fumlgatus to layer chicks revealed that clinieal symptoms and postmortem lesions were as that of the natural infeetion. Control of aspergillosis at the present study lllustrated that there was no feasible effective treatment for aspcrglllosis.

It could be concluded that the mycotic diseases of chicken particularly asperglllosis in duced some losses among infeeted farms and usually has systemic Infection. Control of aspergillosis at the present study Indicated that there was no feasible treatment for asperglllosis, so affected birds should be destroyed and the poultry houses should be vigorously cleaned and disinfected. 
Table (1): Species numbers, locality of the farm and ages of the affected flocks.

\begin{tabular}{|c|l|c|c|c|}
\hline No & Layer species & Locality of the farm & $\begin{array}{c}\text { Number of layer } \\
\text { per flock }\end{array}$ & Age of chicks \\
\hline 1 & Shever & Belbies & 20000 & 4 weeks \\
\hline 2 & & Mashtol & 15000 & 8 weeks \\
\hline 3 & Native layer & Kafr Sager & 15000 & 2 weeks \\
\hline 4 & & Dearp Negen & 5000 & 24 weeks \\
\hline 5 & & El-Salhia & 20000 & 6 weeks \\
\hline 6 & & El-Salhia & 25000 & 18 weeks \\
\hline
\end{tabular}

Table (2):

\begin{tabular}{|c|c|c|c|c|c|}
\hline Group & Infection & Treated & Morbidity & Mortality & Reisolation \\
\hline A & - & - & - & - & - \\
\hline B & + & - & $24 / 30$ & $7 / 30$ & $5 / 5$ \\
\hline C & + & + & $23 / 30$ & $4 / 30$ & $4 / 5$ \\
\hline
\end{tabular}



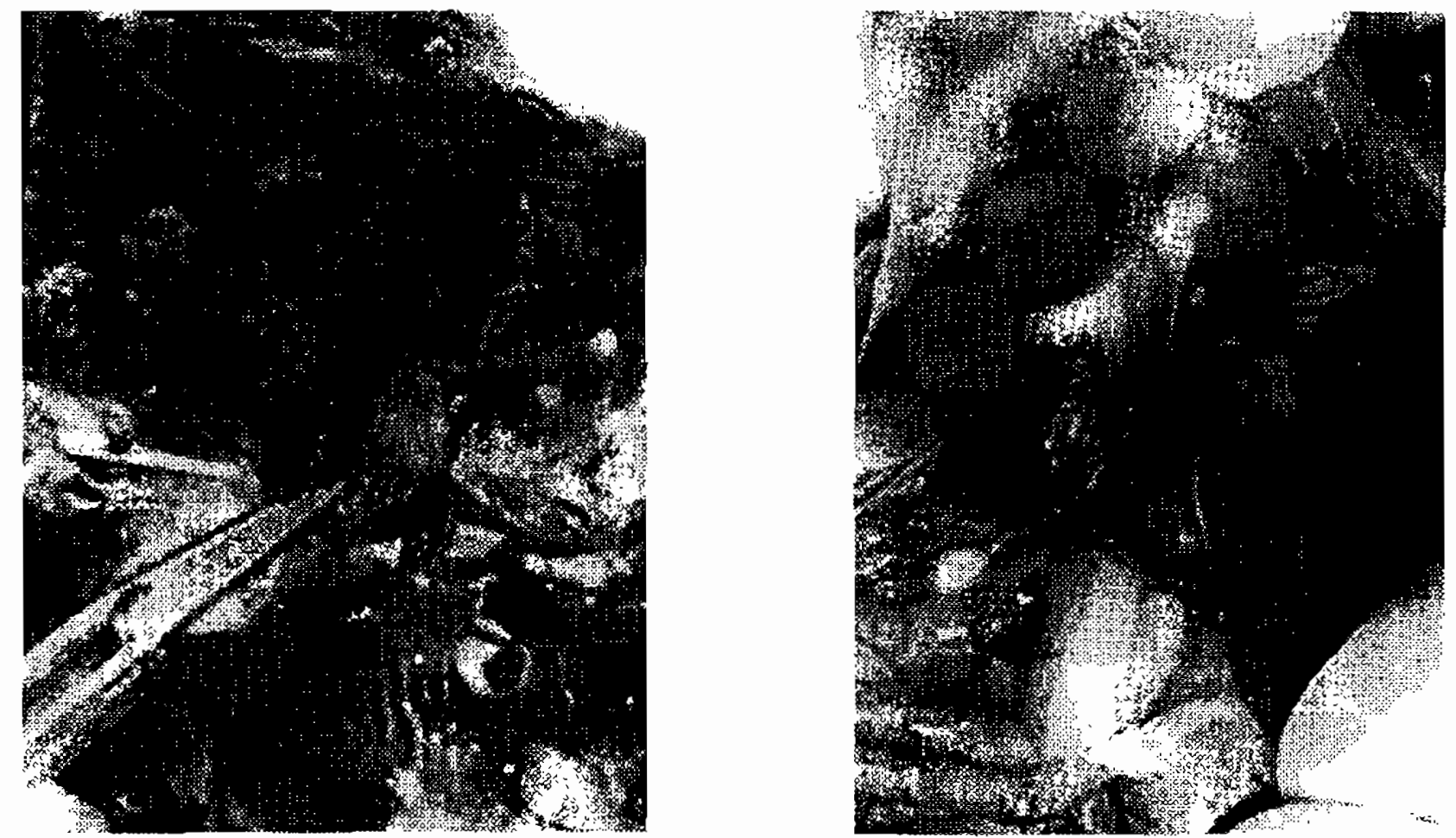

Flg. ( 1 and 2) : Caseous nodules on lung (L). air sacs (A). liver (V) and heart (H).

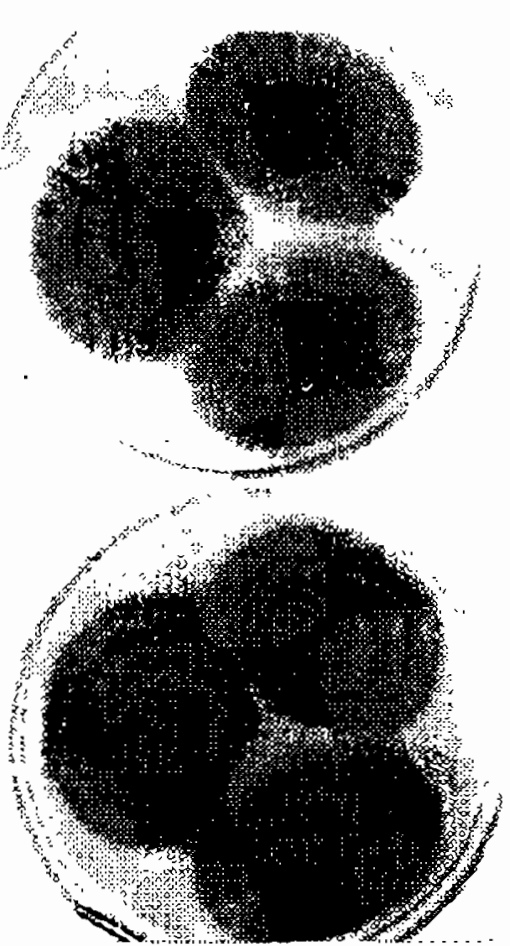

Fig. (3): Asperglllus culture on Sabouraud's agar.

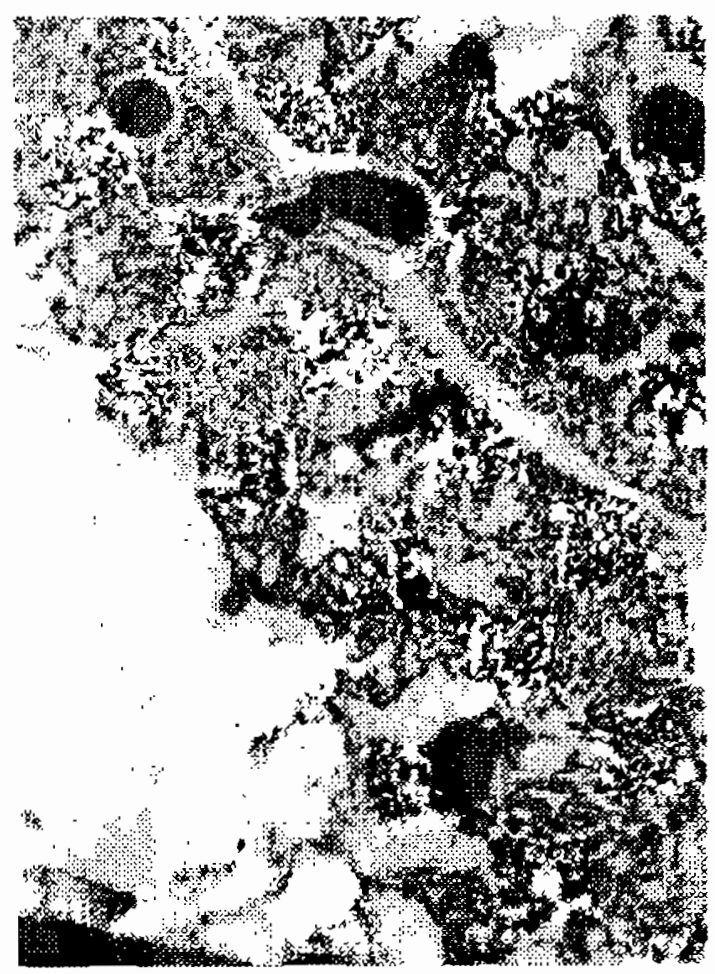

Fig. (4): Lung showing heavy lymphocytic infiltration and nodular formation ( $\mathrm{H}$ \& E $\times 150$ ). 


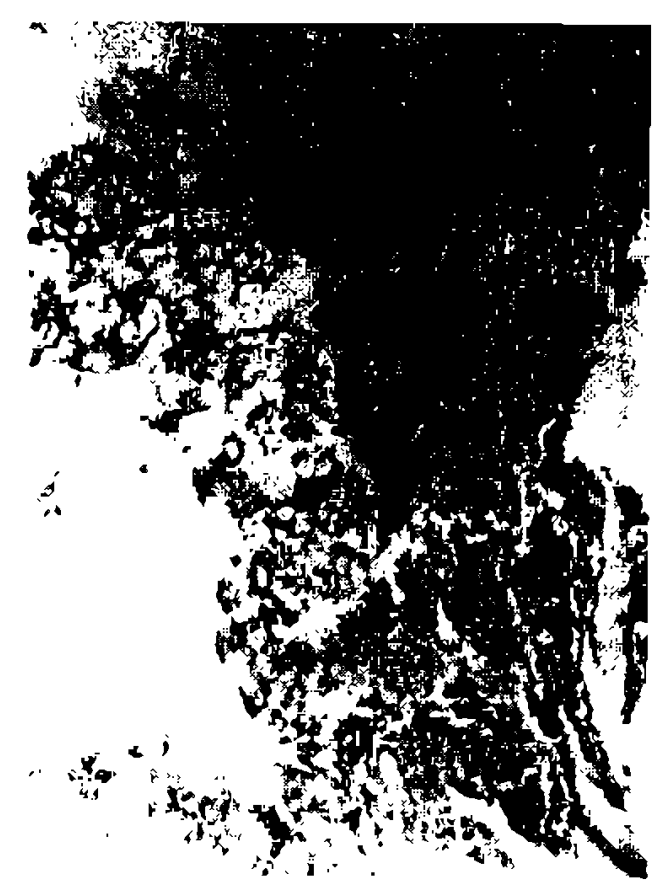

Fig. (5): Lung showing areas of granulomatous necrosis, Inflammatory cell inflltration. llbrosls and fungal hyphae (H \& Ex 150).

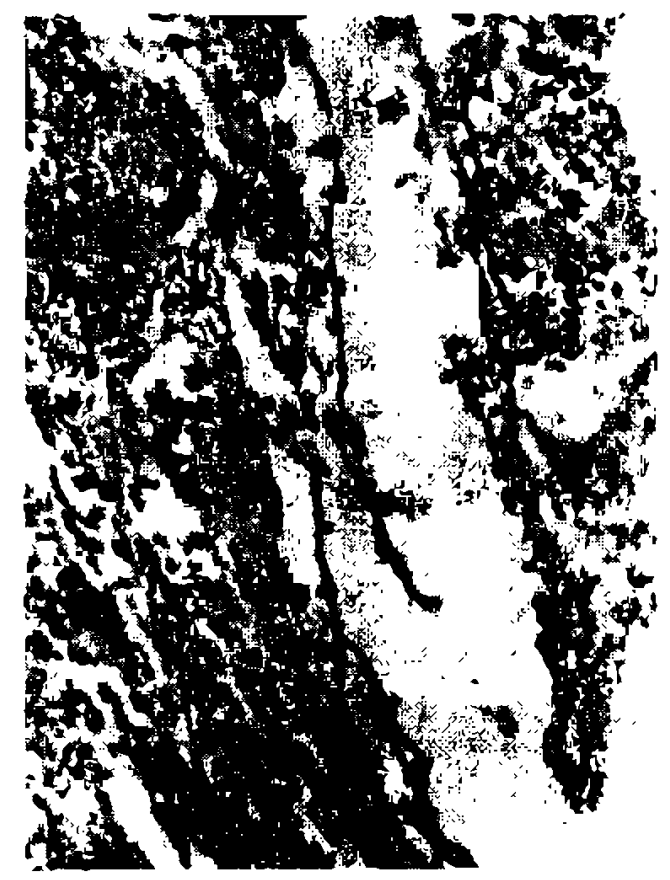

Fig. (6): High power of fig. (5) showing the hyphae, glant eells, granulomatous nodules (H \& E x 300).

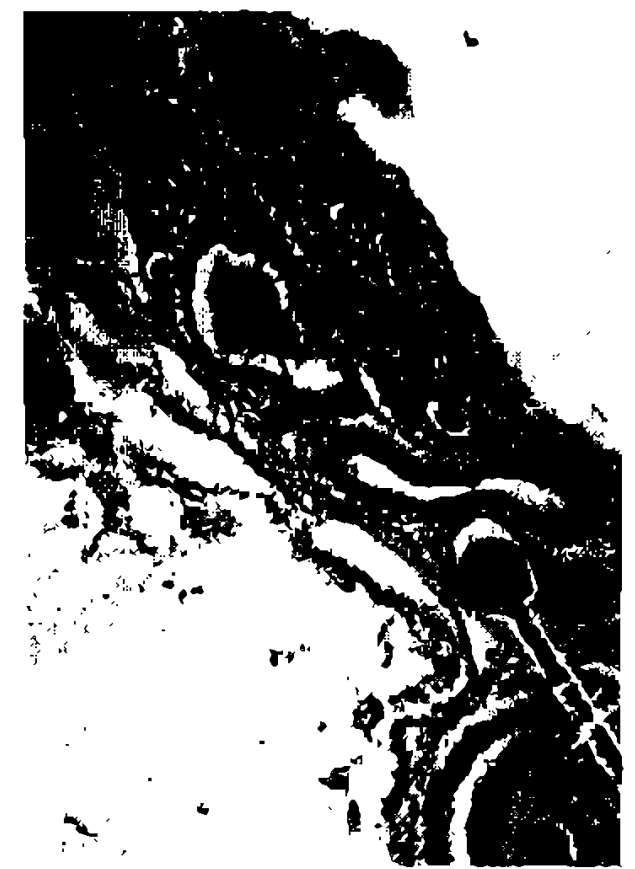

F1g. (7): Wall of alr sac showing thickmis with nodular formation (H \& $\mathrm{E}$; 150).

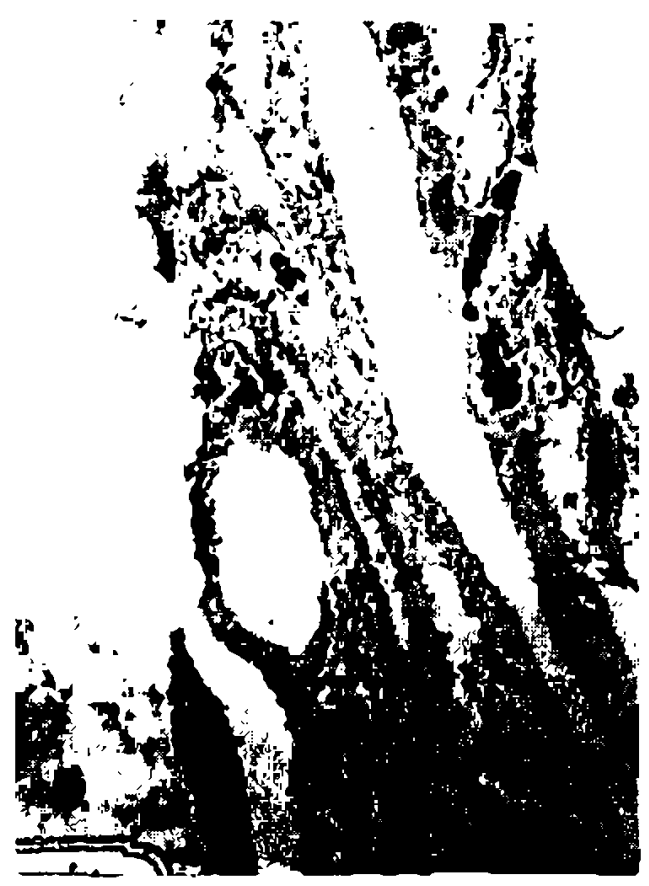

Fig. (8): Wall of alr sac showing hyphae and granulomatous nodules ( $H \& E x$ 150). 


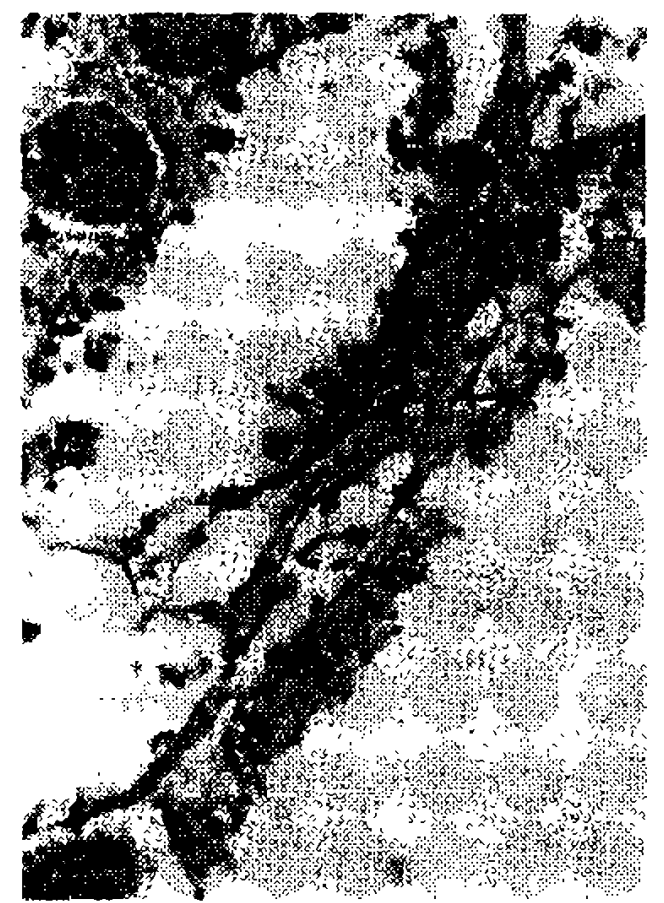

Fig. (9) : High power of Ig. (8) showing the nodules (H \& E x 300).

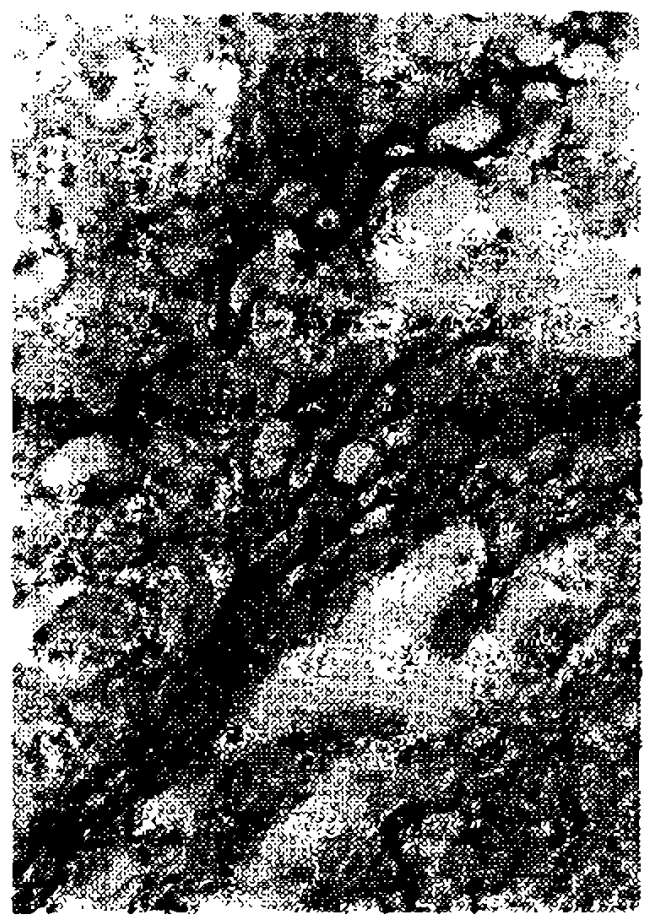

Fig. (10): Wall of alr sac showing hyphae. spores and granulomatous nodules (H \& E x 30O).

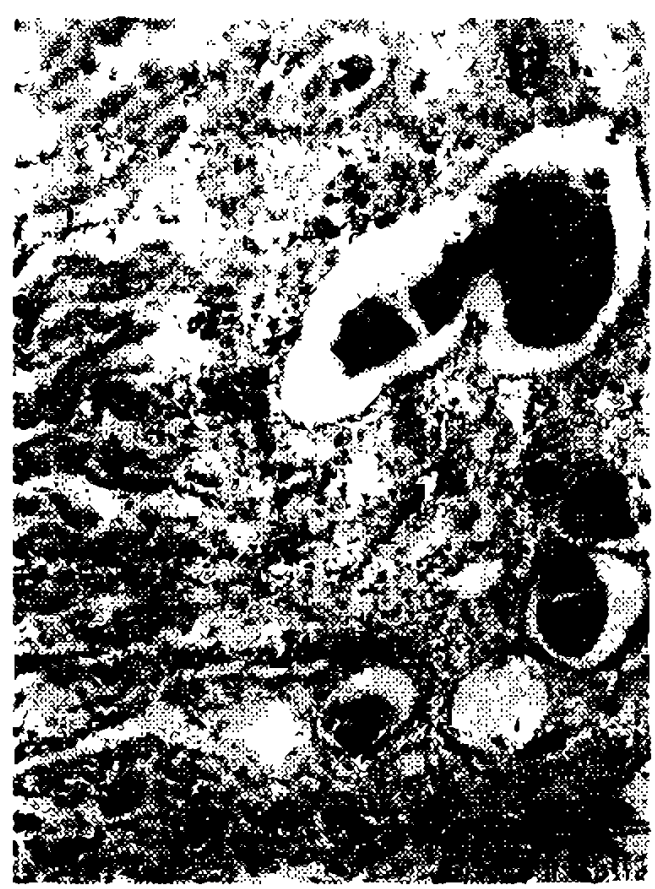

Fig. (1 1): Heart showing thickening of the eplcardium. necrotic nodules and lymphocytic infiltration (H $8 \times E \times 150)$.

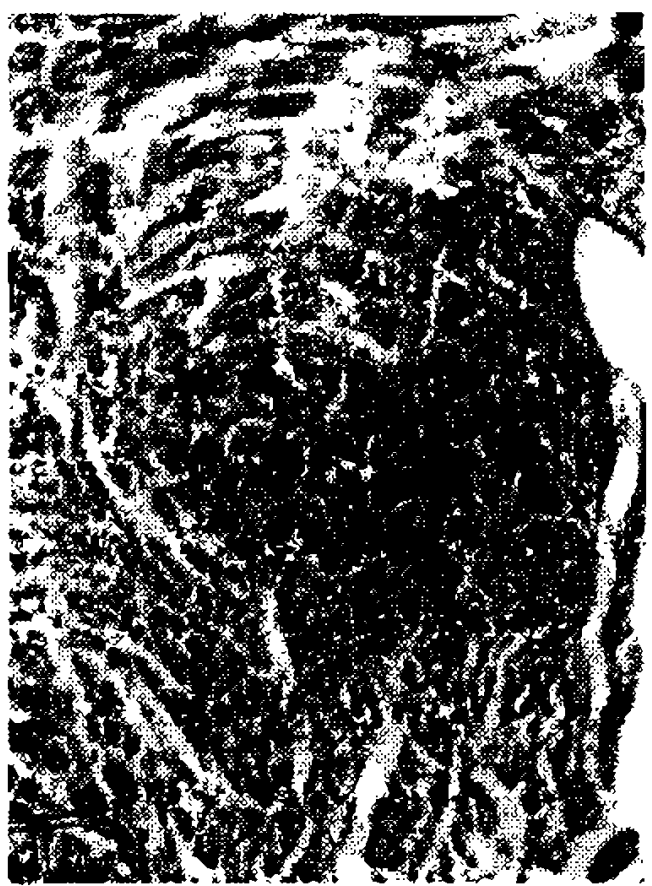

Fig. (12): Heart shouing myocardlum with lymphocyllc Inflitration (H \& E x 150) 


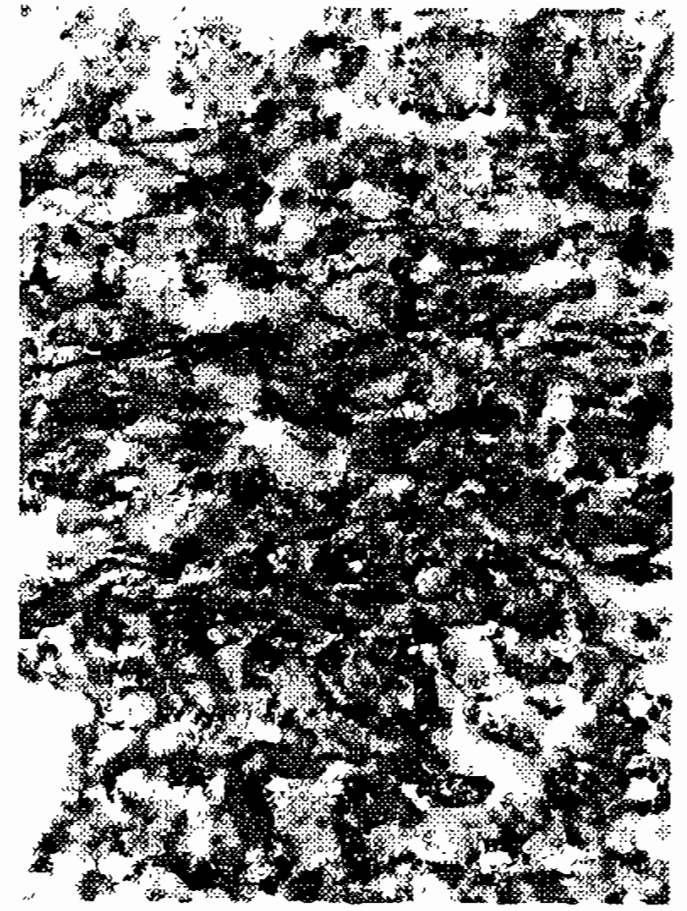

Fig. (19): Heart showing flungal hyphae (H \& E. $\times 600$ ).

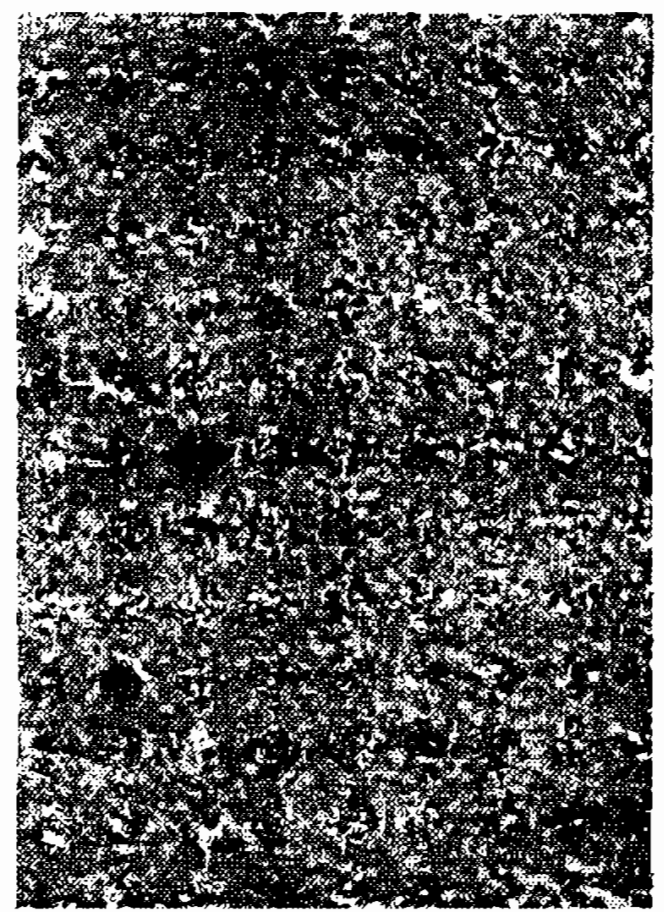

Fig. (14): liver showing multiple easeous nodules (H \& E x 150).

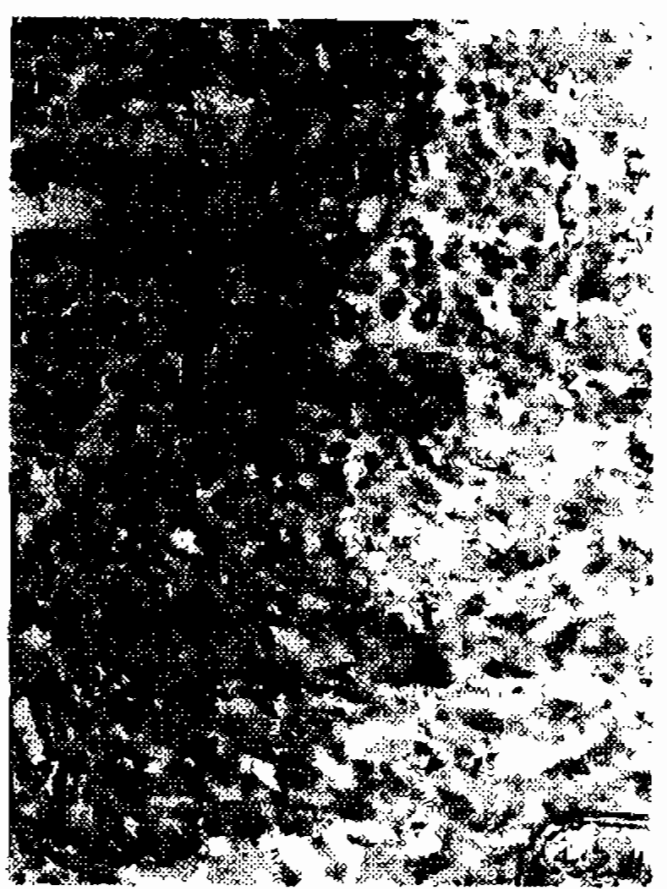

Fig. (15): Liver showing necrotic area and hoavy reactive inflammatory colls. notire newly formcd bylr duclules (H \& E x 300).

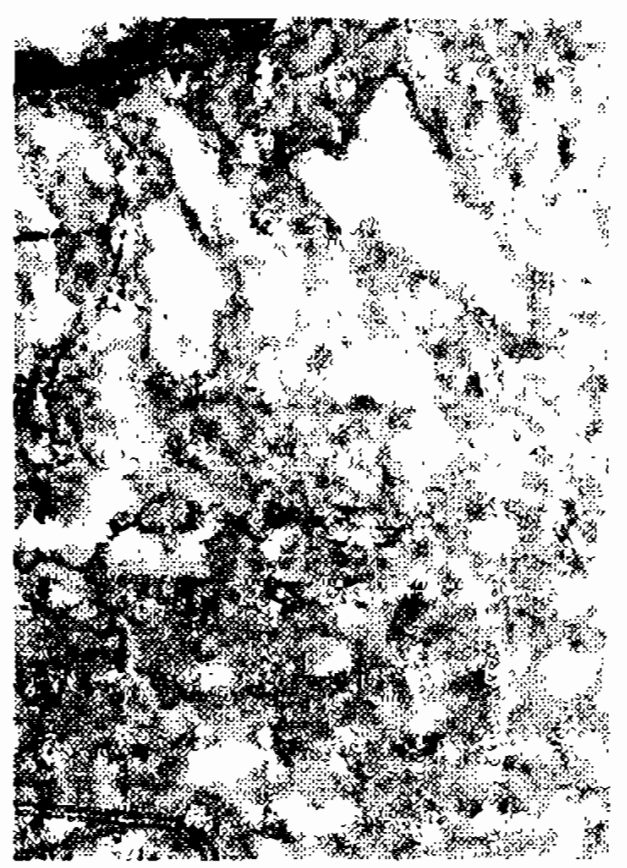

Fig. (16): Llver showing hyphae and hydroptc. degeneration of hepatic cells, notice the liemosidrosis (11 \& \& x 600 ). 


\section{REFERENCES}

Al Doory, G. (1880) : The saprobes: In laboratory medical mycology. Copynght by Lea and Febiger Plilladelphía USA.

All, A. A. (1996) : Pathological studles on Asperglllus fumigatus in both naturally and experimentally infeeted chicken. $3^{\text {rd }}$ Vct. Med. Cong. Zagazig. 8-10 October, 1996.

Bancroft, J. D.; Stereus, A and Turner, D. R. (1990) : Theory and practical of histological tcchniques. $3^{\text {rd }}$ Churchill Living Stone, London and New York.

Beckman, B. J.; Howe, C. W.; Trampel, D. W.; Debey, M. C.: Rdehard J. and Land Niyo, Y. (1994) : Asperglllus fumigatus Ireratits with intraocular invasion in 15day old chicks. Avian Disease. 38: 660665.

Calncek, W. B.; Johan H. and Beard W. C. (1991) : Discase of poultry 9th ed., pp 138 Iowa State Unlv. Press, USA

Corkjsh, J. D. (1982) : Mycotle trachelts in chickens. Avian Pathology, 11:627.

Cutsen, J. and Fram, T. (1987) : Fungal Infcction in birds in captlvity slx case rcports. Mykosen Avlan Discase, 30 (4): 166 171.

Droual, R.; Bickford, A. A and Walker, R. L. [1994] : Flavus in backyard flock of game chicken. Avlan Diseasc, 35: (3): 625 630.

Edris, G. O.; Orahy, F. A. and Azzam, A. H. (1995) : Some studies of molds in zoo birds of Giza Zoo. Egypt. Vet. Med. Ass.. 55 (12): 635-644.

El-Badry, A. A and Sokkar, 1. M. (1988) : Mycotlc flora of chicken population In Kena Governorate. Assuite Vet. J. 19 (38): 173.

Gab-Allah, M. G. (1994) : Pathological studies on myeottc Aspergillus fumigatus Infec-
Hon. Egypt. J. Comp. Pathol. Clin. Path., 6.

Ibrahlm, A. A.; Atln, M. A and Bhehata, M. A (1983) : Some studies on fungl Isolated from a broller noek. Asslut Vet. Med. J., Vol. (10): 20.

Lille, R. D. (1984) : Histophathological teehnlque $3^{\text {rd }}$ ed. The Blankiston Company, Philadelphla.

Mahmoud, A Z. (1988) : Contact infection with Aspergillosis of pigeons.pathology of the respiratory system in the diseased and Its role In natural in fection with asperglllus fumigatus. Asslut Vet. Med. J. Vol. 20, No. 39.

Micoyic, S.; Misur $Z$. and Jurisegic $B$. (1986) : Asperglllosis in poultry with speclal reference to pathological inding in the lung with hematoxyllne eosin staining. Veternarla Yugoslavia, 35 (4): 553 - 558.

Mitrolu, P.; Jivoln, P. and Blrbu, Z. (1962) : Pathogenicity of Asperglllus fumigatus and the lesions in avlan aspergillosis. Lucr. Inst. Cerc. Vet. Bloperp. Pasteur. 1: 473 481.

Ononiwu, J. C. and Momoh, M. A (1983) : An outbreak of Asperglllosis in poultry. Bulleten of AnImal Health and Production In Arrica. 31:1, 75

Pal, M.; Parajapati, S. and Gamgo, R. M. (1990) : Aspergillus fumlgatus as a eause of mycotic trachitis in chicken mycosis. Dept. of Vet. Publlc Health College of Vet. Scl. 33 (2): $70-72$.

Pandita, A; Sadana, J. R. and Aarank, L. (1991) : Studles on clintcal signs and haematological alteration in pneumonlc Asperglllosls. Japanese Quall Mycopathologla. $116(2): 119-123$.

Richard, J. L.; Calnek, B. W. and Reld, W. 
M. (1094) : Aspergillus flavus kerattts with intraocular Invasion in 15 day old chick, lowa State Universlty Press Ames. lowa. 326 - 334.

Rowell, R. E. (1949) : Incidence of Aspergllo- sis In captlve and wild birds. J. Comp. Path. 59: 213.

Saml, A. A. and Sabry, M. M. (2004) : Effect of Asprgillosis on broller chicks $7^{\text {th }}$ Vet. Zag. Conferenee 21, 25 July 2-240-255. 


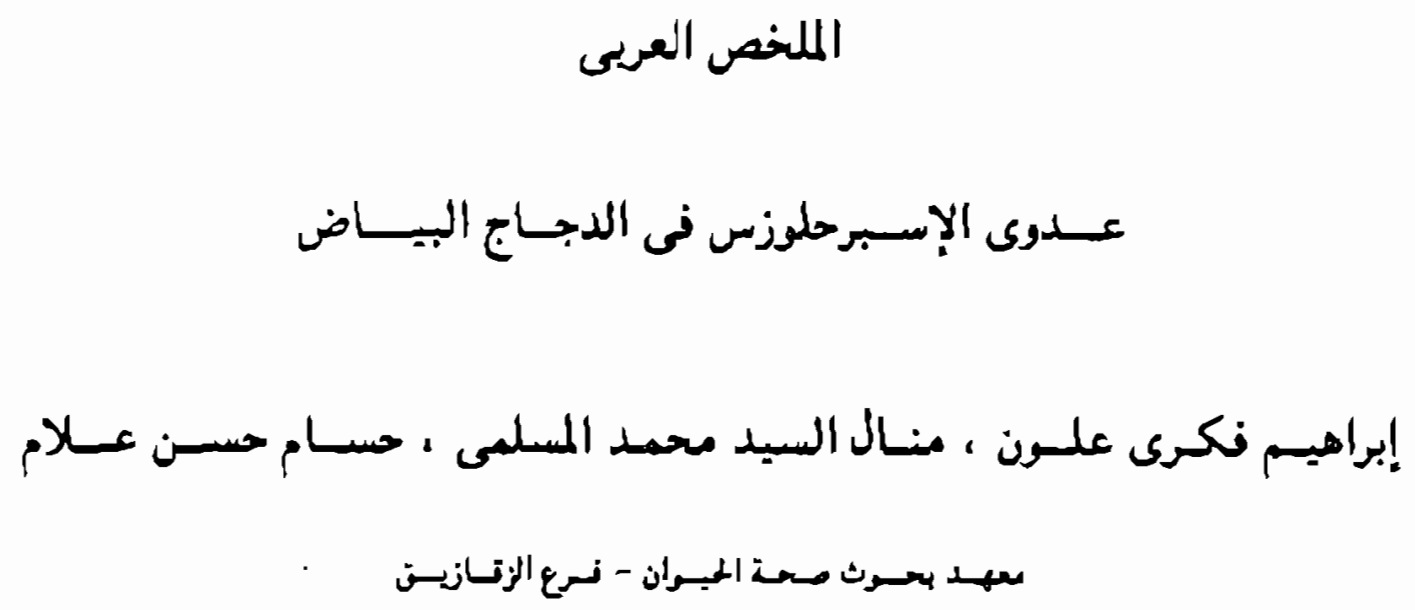

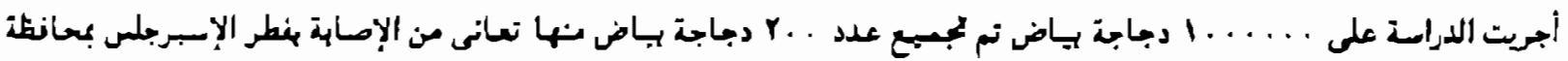

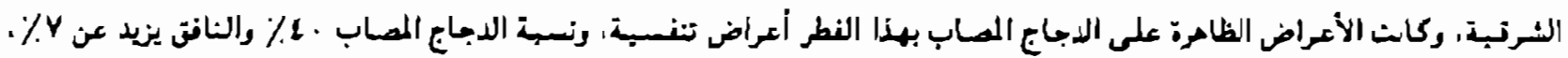

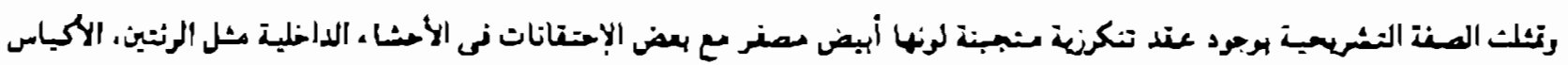
الهرانبة، الثلب، الكيهد.

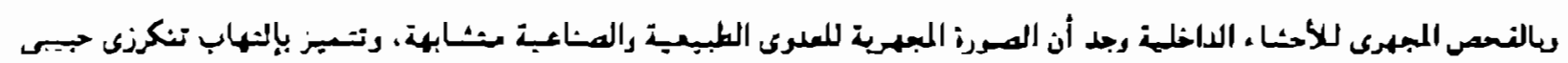

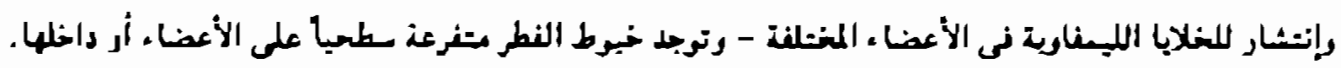

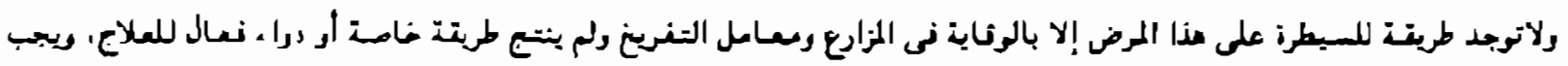
التخلص من التطبع المساب رتنظبف حظانر التربية جيدأ رتطريرها. 